\title{
Heterogeneity of Acute Intermittent Porphyria: A Subtype with Normal Erythrocyte Porphobilinogen Deaminase Activity in Germany $\left.{ }^{1}\right),{ }^{2}$ )
}

\author{
Ulrich Groß. Michael Honcamp and Manfred O. Doss
}

Abteilung für Klinische Biochemie, Klinikum der Philipps-Universität Marburg, Deutschland

Summary: Patients with acute intermittent porphyria can be subdivided into three groups, according to the porphobilinogen deaminase activity in their erythrocytes. The first group has lowered, the second overlapping and the third normal porphobilinogen deaminase activity. Of 385 acute intermittent porphyria patients $5 \%$ had normal porphobilinogen deaminase activity. Gene carriers of acute intermittent porphyria, which have normal porphobilinogen deaminase activity but display slight, moderate or high aberrations of excretion, are recognized by analysis of urinary haem precursors and faecal porphyrins. Six individuals suffering from acute intermittent porphyria were detected in three families with normal porphobilinogen deaminase. There were no differences in the latent and clinical phases of acute intermittent porphyria between patients with lowered and those with normal porphobilinogen deaminase. One female with normal activity in erythrocytes, in which the porphyria disease process is triggered by barbiturates and carbamazepin, is presented. After therapy with high doses of glucose and omission of inducing agents, this woman was free of symptoms, and the excretion of different urinary porphyrin precursors and porphyrins decreased by between 65 and $93 \%$.

\section{Introduction}

Acute intermittent porphyria is an inborn error of haem metabolism and its inheritance is autosomal dominant. More than 60 mutations causing acute intermittent porphyria, have been described so far $(1,2)$. These gene defects cause an enzyme deficiency, which is characterized by decreased activity of porphobilinogen deaminase $^{3}$ ) in most tissues. The diminished porphobilinogen deaminase activity and induction of hepatic 5-aminolaevulinate synthase by haem deficiency leads to the enhanced excretion of the haem precursors, 5-aminolaevulinic acid, porphobilinogen and porphyrins $(3,4)$. For the diagnosis and detection of gene carriers, porphobilinogen deaminase is measured in erythrocytes. In heterozygotes, enzyme activity is diminished to $40-60 \%$ of the normal range $(3,4)$. A minor group of symptomatic and asymptomatic acute intermittent porphyria patients with typical diagnostic excretory patterns of porphyrin precursors and porphyrins do not exhibit significant variations of porphobilinogen deaminase activity in erythrocytes $(5,6)$ compared with controls.

\footnotetext{
') Presented in part at the "International Conference Porphyrins, Porphyria and Photodynamic Therapy", 22-26 November, 1993, Melbourne, Australia, and at the "International Symposium on Porphyrias and Heme Related Disorders", Helsinki, Finland, June 28July 2, 1995.

2) This study was supported by the Hans-Fischer-Gesellschaft, Munich.

3) Enzymes:

5-Aminolaevulinate synthase (EC 2.3.1.37);

Porphobilinogen deaminase (EC 4.3.1.8).
}

The aim of the study was to detect and characterize the acute intermittent porphyria patients with normal porphobilinogen deaminase activity in the erythrocytes in our porphyrin consultation over a period of 20 years. Studies were carried out on the families of three of these patients.

\section{Patients and Methods}

Porphobilinogen deaminase activity was measured by the method of Doss \& von Tiepermann (7) and defined as nmol uroporphyrin per litre erythrocytes per second formed from exogenous porphobilinogen. The enzyme activity was analysed in 385 patients. Diagnosis of acute intermittent porphyria was established by the characteristic excretion of haem precursors in urine and faeces. 5-Aminolaevulinic acid and porphobilinogen were determined by ion exchange chromatography. Porphyrins were analysed spectrophotometrically as methyl esters after separation by high performance thin layer chromatography (8). The patients suffered from a complex abdominal and neurological syndrome.

\section{Results}

Heterogeneity of acute intermittent porphyria

The reference value for porphobilinogen deaminase activity, as determined by the method used, is $18 \pm 4$ nkat $/ 1(\bar{x} \pm \mathrm{SD}, \mathrm{n}=274, \mathrm{CV}=22 \%)$. We investigated 385 patients (male : female $=1: 2.2$ ) with acute intermittent porphyria. Eightyseven percent of these persons $(n=334)$ showed a lowered activity of porphobilinogen deaminase, $(29-71 \%)$ compared with the control group. Nineteen patients $(5 \%)$ had normal porphobilinogen deaminase activity $(85-110 \%)$ and $8 \%(n=32)$ ex- 
Tab. 1 Metabolic excretion of porphyrins and their precursors in patients $\left(\tilde{x}, x_{\min }-x_{\max }, \quad n=19\right)$ suffering from acute

\begin{tabular}{|c|c|c|c|c|c|c|c|}
\hline \multirow[t]{2}{*}{ Excretion } & \multirow[t]{2}{*}{ Metabolites } & \multicolumn{3}{|c|}{ Acute intermittent porphyria } & \multicolumn{3}{|c|}{ Normal } \\
\hline & & $x_{\min }$ & $\tilde{x}$ & $x_{\max }$ & $x_{\min }$ & $\tilde{x}$ & $x_{\max }$ \\
\hline \multirow[t]{3}{*}{ Urinary } & $\begin{array}{l}\text { 5-aminolaevulinic acid }[\mu \mathrm{mol} / 24 \mathrm{~h}] \\
\text { porphobilinogen }[\mu \mathrm{mol} / 24 \mathrm{~h}]\end{array}$ & $\begin{array}{l}50 \\
10\end{array}$ & $\begin{array}{l}187 \\
197\end{array}$ & $\begin{array}{l}902 \\
572\end{array}$ & $\begin{array}{l}2 \\
1\end{array}$ & $\begin{array}{r}22 \\
3\end{array}$ & $\begin{array}{r}49 \\
8\end{array}$ \\
\hline & $\begin{array}{l}\text { uroporphyrin [nmol/24 h] } \\
\text { coproporphyrin [nmol/24 h] }\end{array}$ & $\begin{array}{r}41 \\
135\end{array}$ & $\begin{array}{l}987 \\
521\end{array}$ & $\begin{array}{l}7399 \\
2800\end{array}$ & $\begin{array}{r}4 \\
21\end{array}$ & $\begin{array}{r}17 \\
106\end{array}$ & $\begin{array}{r}29 \\
119\end{array}$ \\
\hline & total porphyrins $\mathrm{s}^{\mathrm{a}}[\mathrm{nmol} / 24 \mathrm{~h}]$ & 191 & 2348 & 11449 & $25^{\circ}$ & 135 & 165 \\
\hline \multirow[t]{2}{*}{ Faecal } & $\begin{array}{l}\text { coproporphyrin [nmol/g dry weight] } \\
\text { protoporphyrin [nmol/g dry weight] }\end{array}$ & $\begin{array}{r}8 \\
28\end{array}$ & $\begin{array}{l}24 \\
93\end{array}$ & $\begin{array}{r}60 \\
199\end{array}$ & $\begin{array}{r}5 \\
21\end{array}$ & $\begin{array}{l}11 \\
43\end{array}$ & $\begin{array}{r}37 \\
151\end{array}$ \\
\hline & total porphyrins ${ }^{b}$ [nmol/g dry weight] & 50 & 120 & 311 & 27 & 65 & 224 \\
\hline
\end{tabular}

a The difference between total porphyrins and the sum of uro- and coproporphyrin is due to the presence of other porphyrins.

hibited an activity within the overlapping range (72$84 \%)$.

\section{Acute intermittent porphyria patients with normal porphobilinogen deaminase activity in erythrocytes}

Diagnosis of acute intermittent porphyria, with normal porphobilinogen deaminase activity in the erythrocytes, is based on the increased excretion of urinary 5-aminolaevulinic acid and porphobilinogen as well as of porphyrins. Table 1 shows urinary and faecal excretion of haem precursors in the group displaying normal enzyme activity. Medians of urinary 5-aminolaevulinic acid and porphobilinogen were enhanced 9- and 66-fold, respectively, compared with the median of the control group. The same is valid for urinary uroporphyrin, coproporphyrin and total porphyrins, which were elevated 58-, 5and 17 -fold, respectively. The median of faecal porphyrins was within the normal range (see tab. 1).

\section{Phases of acute intermittent porphyria with} normal porphobilinogen deaminase activity in the erythrocytes

The patients with normal porphobilinogen deaminase activity were investigated according to their excretion levels of haem precursors and the occurrence of clinical symptoms. This investigation showed a 3-, 9- and 26fold enhancement of urinary 5 -aminolaevulinic acid in the compensatory latent, the decompensatory latent (3) and the acute phase, respectively, compared with the median of the normal range. Urinary porphobilinogen was enhanced 15-, 70- and 136-fold (fig. 1) and urinary total porphyrins were increased 8-, 19- and 35-fold in all three phases, respectively, compared with the median of the normal range (fig. 2). However, in the compensatory latent phase of the disease, urinary coproporphyrin excretion is 6-fold higher than urinary uroporphyrin excretion. In the decompensatory latent phase, the ratio intermittent porphyria with normal porphobilinogen deaminase activity in the erythrocytes.

b The difference between total porphyrins and the sum of coproand protoporphyrin is due to the presence of other porphyrins.

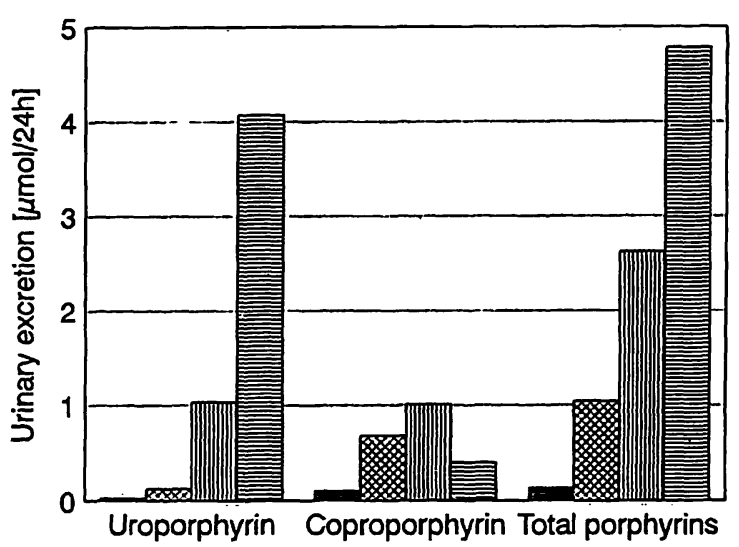

Fig. 2 Medians of urinary uroporphyrin, coproporphyrin and total porphyrins of controls and acute intermittent porphyria patients $(\mathrm{n}=19)$ with normal porphobilinogen deaminase activity in the erythrocytes.
D normal $(n=20)$;
血 decompensatory $(n=7)$;
compensatory $(n=8)$;
目 acute $(n=4)$.

of urinary uroporphyrin and coproporphyrin excretion is $1: 1$. In the acute phase of acute intermittent porphyria, urinary uroporphyrin excretion exceeds urinary coproporphyrin exretion 8-fold (fig. 2).

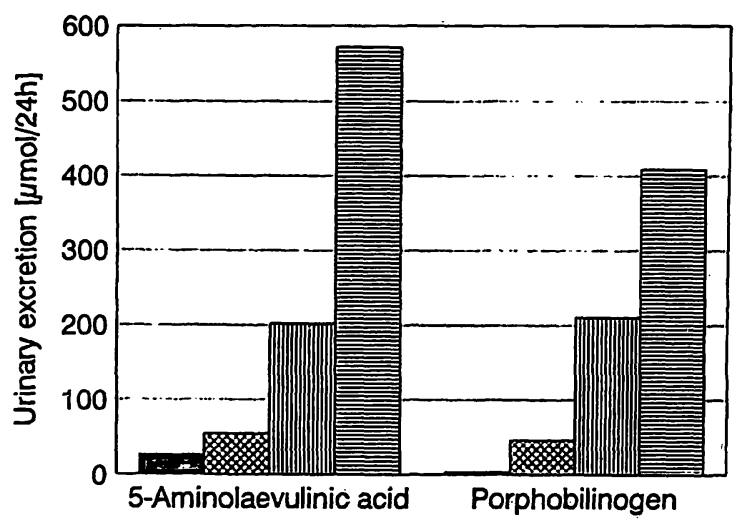

Fig. 1 Medians of urinary 5-aminolaevulinic acid and porphobilinogen of controls and acute intermittent porphyria patients $(n=19)$ with normal porphobilinogen deaminase activity in the erythrocytes.

a normal $(\mathrm{n}=20)$;

血 decompensatory $(\mathrm{n}=7)$;

compensatory $(n=8)$;

首 acute $(n=4)$. 


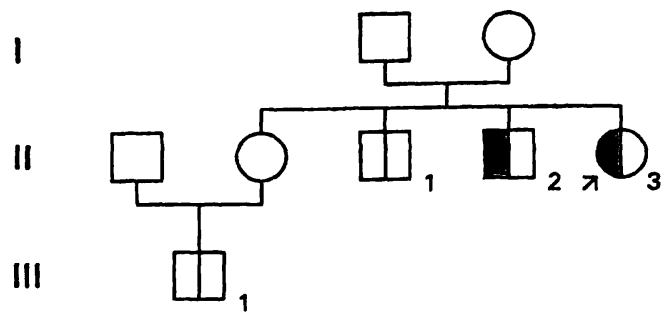

Fig. 3 Relatives of an acute intermittent porphyria patient (family Q) with normal porphobilinogen deaminase activity in the erythrocytes.

OD not tested; $\quad \Phi \square$ normal;

D D heterozygous deficient.

(The propositus is indicated by an arrow.)

\section{Family studies}

Three different families of acute intermittent porphyria patients with normal porphobilinogen deaminase activity were further investigated. In family $\mathrm{Qu}$ (see fig. 3) the acute intermittent porphyria patient (II/3, tab. 2) excreted elevated amounts of urinary haem precursors. The urinary excretions of 5-aminolaevulinic acid, porphobilinogen, uroporphyrin, coproporphyrin and total porphyrins of her brother (II/2, tab. 2) were also enhanced. Another brother (II/1, tab. 2) and the nephew (III/1, tab. 2) showed normal urinary excretion of haem precursors (fig. 3).

Two daughters (family $\mathrm{L}, \mathrm{III} / 1$ and III/2, tab. 3) of an acute intermittent porphyria patient (II/1, tab. 3) with normal porphobilinogen deaminase activity (108\%) were recognized as gene carriers of a porphobilinogen deaminase defect by their enhanced urinary excretory patterns of haem precursors. They exhibited different porphobilinogen deaminase activities, which were 72 and $92 \%$ of the control level. The sister of this patient (II/2, tab. 3) showed normal excretion of urinary haem precursors (fig. 4, family L).

A third family (family $F$, fig. 5) was investigated. A female (III/4, tab. 4), suffering from acute intermittent porphyria, excreted high amounts of urinary haem pre- cursors. The grandmother (I/1), mother (II/3), the uncle (II/2) and his wife (II/1) and three cousins (III/1, III/2, III/3) showed normal urinary excretion of porphyrin precursors and porphyrins (see tab. 4). However, the grandmother was reported not to tolerate alcohol, and to present with abdominal pain, vomiting and shortness of breath. At the time of these symptoms, the urinary porphobilinogen and total porphyrins of the grandmother were reported to be increased 88- and 29-fold, respectively, compared with the median of the normal range. The mother suffered from psychosis, abdominal colics, nausea, muscular weakness and paresis of the legs. At the time of these symptoms the urinary porphobilinogen of the mother was elevated at $305 \mu \mathrm{mol} / 24 \mathrm{~h}$.

A fourth family with acute intermittent porphyria and normal porphobilinogen deaminase activity in the erythrocytes was reported from the south of Germany. A female with urinary excretion of

$\begin{array}{ll}\text { 5-aminolaevulinic acid } & =165 \mu \mathrm{mol} / 24 \mathrm{~h}, \\ \text { porphobilinogen } & =213 \mu \mathrm{mol} / 14 \mathrm{~h}, \\ \text { uroporphyrin } & =854 \mathrm{nmol} / 24 \mathrm{~h}, \\ \text { coproporphyrin } & =981 \mathrm{nmol} / 24 \mathrm{~h}, \\ \text { total porphyrins } & =2515 \mathrm{nmol} / 24 \mathrm{~h}\end{array}$

and normal faecal porphyrins showed $97 \%$ porphobilinogen deaminase activity in the erythrocytes compared with the control. Two brothers of this patient showed elevated urinary haem precursors. Another brother and the sister excreted normal amounts of urinary porphyrin precursors and porphyrins. The siblings had $100 \pm 5 \%$ $(\bar{x} \pm \mathrm{SD})$ porphobilinogen deaminase activity in the erythrocytes compared with the control (K. Jacob, personal communication).

\section{Course of acute intermittent porphyria in a female}

The female acute intermittent porphyria patient (III/4 fig. 5 and tab. 4) from family $F$ with normal porphobili-
Tab. 2 Urinary excretion of haem precursors by family members (family $\mathrm{Qu}$ ) and a patient suffering from acute intermittent por-

phyria $^{a}$ with normal porphobilinogen deaminase activity in the erythrocytes. (Numbers of family members according to fig. 3 ).

\begin{tabular}{|c|c|c|c|c|c|}
\hline Metabolites & II $/ 1$ & $\mathrm{II} / 2$ & $\mathrm{II} / 3$ & III/1 & Normal \\
\hline $\begin{array}{l}\text { 5-Aminolaevulinic acid }[\mu \mathrm{mol} / 24 \mathrm{~h}] \\
\text { Porphobilinogen }[\mu \mathrm{mol} / 24 \mathrm{~h}]\end{array}$ & $\begin{array}{r}26 \\
4\end{array}$ & $\begin{array}{l}51 \\
20\end{array}$ & $\begin{array}{r}138 \\
52\end{array}$ & $\begin{array}{l}8 \\
2\end{array}$ & $\begin{array}{l}<49 \\
<8\end{array}$ \\
\hline $\begin{array}{l}\text { Uroporphyrin [nmol/24 h] } \\
\text { Coproporphyrin [nmol/24 h] }\end{array}$ & $\begin{array}{r}22 \\
114\end{array}$ & $\begin{array}{r}43 \\
400\end{array}$ & $\begin{array}{l}181 \\
959\end{array}$ & $\begin{array}{l}10 \\
75\end{array}$ & $\begin{array}{l}<29 \\
<119\end{array}$ \\
\hline Total porphyrins ${ }^{b}[\mathrm{nmol} / 24 \mathrm{~h}]$ & 151 & 532 & 1421 & 94 & $<165$ \\
\hline $\begin{array}{l}\text { Porphobilinogen deaminase in erythrocytes } \\
\text { in } \% \text { of controls }\end{array}$ & 104 & 85 & 88 & 100 & $85-110$ \\
\hline
\end{tabular}

a Faecal excretion: coproporphyrin $=10 \mathrm{nmol} / \mathrm{g}$ dry weight $[(\tilde{x}$, $\mathrm{n}=4$ ); normal: $5-37 \mathrm{nmol} / \mathrm{g}$ dry weight], protoporphyrin: 75 $\mathrm{nmol} / \mathrm{g}$ dry weight $[(\tilde{x}, \mathrm{n}=4)$; normal: $21-151 \mathrm{nmol} / \mathrm{g}$ dry weight), total porphyrins $=102 \mathrm{nmol} / \mathrm{g}$ dry weight $[(\tilde{x}, n=4)$; normal: $27-224 \mathrm{nmol} / \mathrm{g}$ dry weight]. b The difference between total porphyrins and the sum of uro- and coproporphyrin is due to the presence of other porphyrins. 
Tab. 3 Urinary excretion of hacm precursors by family members (family L) and patients suffering from acute intermittent por- phyria ${ }^{\text {a }}$ with normal porphobilinogen deaminase activity in the erythrocytes. (Numbers of family members according to fig. 4).

\begin{tabular}{|c|c|c|c|c|c|}
\hline Metabolites & $\mathrm{II} / \mathrm{I}$ & $I I / 2$ & $\mathrm{III} / 1$ & III/2 & Normal \\
\hline $\begin{array}{l}\text { 5-Aminolaevulinic acid }[\mu \mathrm{mol} / 24 \mathrm{~h}] \\
\text { Porphobilinogen }[\mu \mathrm{mol} / 24 \mathrm{~h}]\end{array}$ & $\begin{array}{l}318 \\
245\end{array}$ & $\begin{array}{r}29 \\
5\end{array}$ & $\begin{array}{l}50 \\
12\end{array}$ & $\begin{array}{l}67 \\
68\end{array}$ & $\begin{array}{l}<49 \\
<8\end{array}$ \\
\hline $\begin{array}{l}\text { Uroporphyrin [nmol/24 h] } \\
\text { Coproporphyrin [nmol/24 h] }\end{array}$ & $\begin{array}{r}4069 \\
339\end{array}$ & $\begin{array}{r}16 \\
112\end{array}$ & $\begin{array}{r}41 \\
135\end{array}$ & $\begin{array}{l}108 \\
612\end{array}$ & $\begin{array}{l}<29 \\
<119\end{array}$ \\
\hline Total porphyrins $^{\mathrm{b}}[\mathrm{nmol} / 24 \mathrm{~h}]$ & 4783 & 154 & 211 & 1197 & $<165$ \\
\hline $\begin{array}{l}\text { Porphobilinogen deaminase in } \\
\text { erythrocytes in \% of controls }\end{array}$ & 108 & 104 & 92 & $72^{\prime}$ & $85-110$ \\
\hline
\end{tabular}

a Faecal excretion: coproporphyrin $=33 \mathrm{nmol} / \mathrm{g}$ dry weight $[(\bar{x}$, $\mathrm{n}=4$ ); normal: $5-37 \mathrm{nmol} / \mathrm{g}$ dry weight], protoporphyrin $=131$ $\mathrm{nmol} / \mathrm{g}$ dry' weight $[(\tilde{x}, \mathrm{n}=4)$; normal: $21-151 \mathrm{nmol} / \mathrm{g}$ dry weight), total porphyrins $=164 \mathrm{nmol} / \mathrm{g}$ dry weight $[(\tilde{x}, \mathrm{n}=4)$; normal: $27-224 \mathrm{nmol} / \mathrm{g}$ dry weight].

nogen deaminase activity was 20 years old and had a six year history of her disease. She suffered from abdominal pain, nausea, and vomiting over 5 years and underwent a laparoscopy because cancer of the adnexes was suspected. No pathological findings were revealed in the uterus, adnexes and appendix, but she had repeated, convulsive abdominal pain, due to the application of barbiturates for narcosis. An electro-encephalogram was interpreted as indicative of epilepsy. Thus she was treated with carbamazepin $(2 \times 200 \mathrm{mg}$ per day $)$,

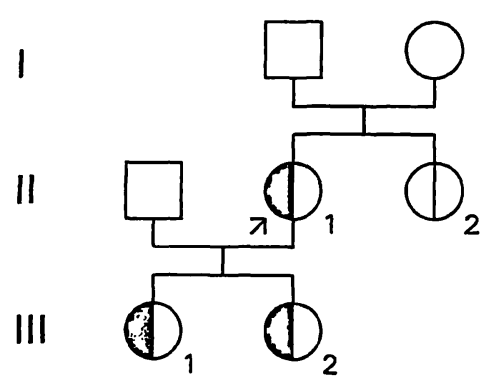

Fig. 4 Relatives of an acute intermittent porphyria patient (family L) with normal porphobilinogen deaminase activity in the erythrocytes.

O $\square$ not tested; (1) normal;

D D heterozygous deficient.

(The propositus is indicated by an arrow.)

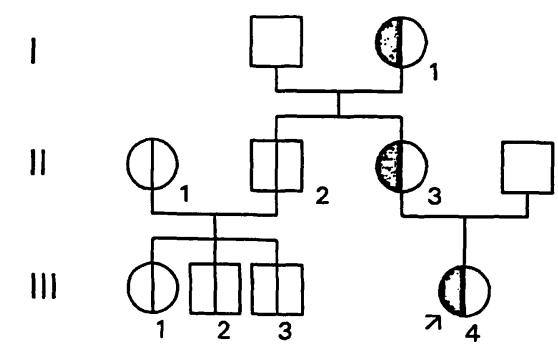

Fig. 5 Relatives of an acute intermittent porphyria patient (family F) with normal porphobilinogen deaminase activity in the erythrocytes.

O $\mathrm{not}$ tested; $\quad$ (ए) normal;

D D heterozygous deficient. 0 suspected to be deficient. (The propositus is indicated by an arrow.) b The difference between total porphyrins and the sum of uro- and coproporphyrin is due to the presence of other porphyrins.

and her state of health worsened. She exbibited pain in the legs and arms, abdominal colics, muscular weakness and dizziness. Urinary haem precursors were analysed (see day 0, tab. 5). Urinary 5-aminolaevulinic acid and porphobilinogen were elevated 41 - and 99-fold, respectively, while urinary uroporphyrin, coproporphyrin, and total porphyrins were enhanced 214-, 16- and 43-fold, respectively, compared with the median of the normal range. At day 16 , high doses of glucose ( $400 \mathrm{~g}$ per day) were applied for three days, and carbamazepin was omitted gradually. At day 18, 22 and 39 haem precursors were decreased by $18-85 \%, 33-80 \%$ and $65-93 \%$, respectively, compared with day 0 (see tab. 5) and the patient was free of symptoms after this period.

\section{Discussion}

The housekeeping and erythroid form of porphobilinogen deaminase are encoded by a single gene with two different promotors (9). It produces two different mRNAs with two, tissue-specific isoenzymes $(10,11)$. Recently the human hepatic isoform of the enzyme has been purified to homogeneity (12). In a Finnish family with acute intermittent porphyria and normal porphobilinogen deaminase activity, a mutation exists in which the enzyme defect is restricted to non-erythroid cells. Transcription of the porphobilinogen deaminase gene in erythroid cells starts 2800 bases downstream from this mutation. For that reason the mutation has no consequence for the expression of the porphobilinogen deaminase gene in erythrocytes (10). Some reported cases of acute intermittent porphyria with normal erythroid activity, but half the normal activity of the housekeeping isoenzyme, are the result of two mutations of the exon $1 /$ intron 1 boundary. These mutations alter the splicing of the hepatic specific transcript (1). We expect similar mechanisms for our acute intermittent porphyria patients with normal porphobilinogen deaminase activity in the erythrocytes. 
Tab. 4 Urinary excretion of haem precursors by family members (family F) and a patient suffering from acute intermittent por- phyria" with normal porphobilinogen deaminase activity in the erythrocytes. (Numbers of family members according to fig. 5).

\begin{tabular}{|c|c|c|c|c|c|c|c|c|c|}
\hline Metabolites & $1 / 1$ & IV $/ 1$ & $\mathrm{II} / 2$ & $\mathrm{II} / 3$ & III/1 & III $/ 2$ & $\mathrm{III} / 3$ & $\mathrm{III} / 4$ & Normal \\
\hline $\begin{array}{l}\text { 5-Aminolaevulinic acid }[\mu \mathrm{mol} / 24 \mathrm{~h}] \\
\text { Porphobilinogen }[\mu \mathrm{mol} / 24 \mathrm{~h}]\end{array}$ & $\begin{array}{r}13 \\
8\end{array}$ & $\begin{array}{l}7 \\
2\end{array}$ & $\begin{array}{r}24 \\
4\end{array}$ & $\begin{array}{r}25 \\
3\end{array}$ & $\begin{array}{r}15 \\
2\end{array}$ & $\begin{array}{r}14 \\
3\end{array}$ & $\begin{array}{r}14 \\
2\end{array}$ & $\begin{array}{l}347 \\
268\end{array}$ & $\begin{array}{l}<49 \\
<8\end{array}$ \\
\hline $\begin{array}{l}\text { Uroporphyrin [nmol/24 h] } \\
\text { Coproporphyrin [nmol/24 h] }\end{array}$ & $\begin{array}{l}10 \\
70\end{array}$ & $\begin{array}{r}5 \\
32\end{array}$ & $\begin{array}{l}12 \\
75\end{array}$ & $\begin{array}{r}6 \\
116\end{array}$ & $\begin{array}{l}12 \\
87\end{array}$ & $\begin{array}{l}14 \\
90\end{array}$ & $\begin{array}{l}12 \\
93\end{array}$ & $\begin{array}{r}1880 \\
966\end{array}$ & $\begin{array}{l}<29 \\
<119\end{array}$ \\
\hline Total porphyrins $^{\mathrm{b}}[\mathrm{nmol} / 24 \mathrm{~h}]$ & 89 & 41 & 97 & 146 & 110 & 115 & 117 & 3159 & $<165$ \\
\hline $\begin{array}{l}\text { Porphobilinogen deaminase in erythrocytes } \\
\text { in } \% \text { of controls }\end{array}$ & 92 & 94 & 90 & 88 & 102 & 87 & 99 & 85 & $85-110$ \\
\hline
\end{tabular}

a Faecal excretion: coproporphyrin $=16 \mathrm{nmol} / \mathrm{g}$ dry weight $[(\tilde{x}$, $\mathrm{n}=8$ ); normal: $5-37 \mathrm{nmol} / \mathrm{g}$ dry weight], protoporphyin $=40$ $\mathrm{nmol} / \mathrm{g}$ dry weight $[(\tilde{x}, \mathrm{n}=8)$; normal: $21-151 \mathrm{nmol} / \mathrm{g}$ dry weight $)$, total porphyrins $=67 \mathrm{nmol} / \mathrm{g}$ dry weight $[(\hat{x}, \mathrm{n}=8)$; normal: $27-224 \mathrm{nmol} / \mathrm{g}$ dry weight].

A variant of acute intermittent porphyria with normal porphobilinogen deaminase activity in the erythrocytes was first reported from Finland (5). The authors suggested, on the basis of 5-aminolaevulinic acid loading tests, that the enzyme defect might be restricted to the liver in this group (6). This indicates that the enzyme in erythrocytes is not involved in the pathobiochemistry of acute intermittent porphyria in this group, and that the housekeeping enzyme is concerned in the disease process. Thus porphobilinogen deaminase is expressed differently in bone marrow and liver. Regulatory mechanisms leading to induction of 5-aminolaevulinate synthase result in the metabolic and clinical expression of acute intermittent porphyria (3), both in patients with decreased, and in those with normal porphobilinogen deaminase activity. Table 1 shows the urinary and faecal excretion of haem precursors in our patients. Although this kind of excretion is characteristic for acute intermittent porphyria, the patients exhibit normal porphobilinogen deaminase activity in the erythrocytes. Therefore this type of acute intermittent porphyria also exists in Germany. An American case with acute intermittent porphyria and normal porphobiliniogen deaminase activity has been identified (13). This subtype of acute intermittent porphyria therefore exists in other populations.

Tab. 5 Urinary excretion of haem precursors by patient IIU/4 (family F) receiving glucose during the acute phase of acute intermittent porphyria with normal porphobilinogen deaminase activity in the erythrocytes, and with omission of carbamazepin.

\begin{tabular}{|c|c|c|c|c|}
\hline \multirow[t]{2}{*}{ Metabolites } & \multicolumn{4}{|l|}{ Day } \\
\hline & 0 & 18 & 22 & 39 \\
\hline $\begin{array}{l}\text { 5-Aminolaevulinic acid }[\mu \mathrm{mol} / 24 \mathrm{~h}] \\
\text { Porphobilinogen }[\mu \mathrm{mol} / 24 \mathrm{~h}]\end{array}$ & $\begin{array}{l}902 \\
297\end{array}$ & $\begin{array}{l}336 \\
243\end{array}$ & $\begin{array}{l}313 \\
198\end{array}$ & $\begin{array}{l}67 \\
68\end{array}$ \\
\hline $\begin{array}{l}\text { Uroporphyrin [nmol/24 h] } \\
\text { Coproporphyrin [nmol/24 h] }\end{array}$ & $\begin{array}{l}3641 \\
1667\end{array}$ & $\begin{array}{l}535 \\
666\end{array}$ & $\begin{array}{l}723 \\
350\end{array}$ & $\begin{array}{r}1266 \\
467\end{array}$ \\
\hline Total porphyrins* [nmol/24 h] & 5766 & 1333 & 1191 & 1924 \\
\hline
\end{tabular}

* The difference between total porphyrins and the sum of uro- and coproporphyrin is due to the presence of other porphyrins. b The difference between total porphyrins and the sum of uro- and coproporphyrin is due to the presence of other porphyrins.

In Finland, the porphobilinogen deaminase mutations with normal acitivty in the erythrocytes comprise $8 \%$ of known porphobilinogen deaminase gene defects (14). In our study $5 \%$ of the acute intermittent porphyria have normal porphobilinogen deaminase activity in the erythrocytes. Thus, in Finland and Germany, the frequency of these mutations with normal porphobilinogen deaminase activity is below $10 \%$.

Acute intermittent porphyria can be classified into different types, according to the level of excretion of urinary haem precursors and the occurrence of clinical symptoms (3). These phases were also observed in acute intermittent porphyria patients with normal porphobilinogen deaminase activity in the erythrocytes, as shown in this paper. They are dependent on the degree of hepatic disregulation of pyrrole-, porphyrin- and haem biosynthesis.

In table 2 the enhanced urinary excretion of haem precursors of person II/2 and II/3 is shown. This indicates the metabolic defect in the compensatory latent phase of acute intermittent porphyria and characterizes these persons as gene carriers.

In family L (tab. 3) the patient (II/1) and her two daughters (III/1, III/2) are shown to have the gene defect by analyses of their urinary and faecal haem precursors. The two daughters exhibited different porphobilinogen deaminase activities in erythrocytes, one being normal and one slightly lowered. There is no genetic reason for this phenomenon. Exogenous influences may be responsible, because the activity of porphobilinogen deaminase is influenced by various factors, for example the age of erythrocytes or haematological disorders with haemolysis and increased erythropoiesis $(6,13)$. Other diseases, which enhance or diminish porphobilinogen deaminase activity, are chronic renal insufficiency, chronic polyarthritis and acute or chronic hepatic infections (15).

In family $F$ (tab. 4) all individuals tested were normal with respect to their exretion of urinary haem precursors, 
with the exception of the patient (III/4). The grandmother and the mother were reported to have visceroneurological symptoms of acute intermittent porphyria. These symptoms were dated to about 20 years ago in the case of the mother and about 30 years ago in the case of the grandmother. At the time of our investigations these relatives were asymptomatic. In this context urinary porphyrin precursors and porphyrin studies did not show positive results. From a retrospective point of view, a manifestation of porphyria years ago might have been possible. This was confirmed by enhanced urinary excretion of porphobilinogen and total porphyrins at the time of symptoms. In rare cases, urinary haem precursors decrease to the normal range after an acute crisis much earlier in the life of the patient.

In the case study, a female acute intermittent porphyria patient with clinical exacerbation of the disease under the influence of barbiturates and carbamazepin is described. The diagnosis was established from the characteristic elevated excretion of haem precursors, while porphobilinogen deaminase activity was normal. Barbi-

\section{References}

1. Lundin G, Hashemi J, Floderus Y, Thunell S, Sagen E, Lægreid $\mathrm{A}$, et al. Four mutations in the porphobilinogen deaminase gene in patients with acute intermittent porphyria. J Med Genet 1995; 32:979-81.

2. Andersson C. Thunell S, Floderus $Y$, Forsell C, Lundin G, Anvret $M$, et al. Diagnosis of acute intermittent porphyria in Northern Sweden: an evaluation of mutation analysis and biochemical methods. J Int Med 1995; 235:301-8.

3. Doss M. Hepatic porphyrias. Pathobiochemical, diagnostic and therapeutic implications. In: Popper H, Schaffner F, editors. Progress in liver diseases. New York: Grune and Stratton, 1982; 8:573-97.

4. Nordmann Y. Human hereditary porphyrias. In: Mclntyre N, Benhamou JP, Bircher J, Rizetto M, Rodes J, editors. Oxford, New York, Tokyo: Oxford Textbook of Clinical Hepatology, Oxford University Press. 1991; 2:974-85.

5. Mustajoki P. Normal erythrocyte uroporphyrinogen I synthase in a kindred with acute intermittent porphyria. Ann Intern Med 1981; 95:162-6.

6. Mustajoki P, Tenhunen R. Variant of acute intermittent porphyria with normal erythrocyte uroporphyrinogen-I-synthase activity. Eur J Clin Invest 1985; 15:281-4.

7. Doss $M$, von Tiepermann R. Uroporphyrinogen-Synthase in Erythrocyten bei akuter intermittierender Porphyrie: Neue pathobiochemische Aspekte. J Clin Chem Clin Biochem 1978; 16:111-8.

8. Doss MO. Porphyrins and porphyrin precursors. In: Curtius $\mathrm{HCh}$, Roth $\mathrm{M}$, editors. Clinical Biochemistry. Principles and Methods. New York: de Gruyter, 1974; 2:1323-71.

9. Yoo HW, Warner CA, Chen CH, Desnick RJ. Hydroxymethylbilane synthase: complete genomic sequence and amplifiable polymorphisms in the human gene. Genomics 1993; 15:21-9.

10. Grandchamp B, Picat C, Kauppinen R, Mignotte V, Peltonen $\mathrm{L}$, Mustajoki $\mathrm{P}$, et al. Molecular analysis of acute intermittent turates and carbamazepin trigger acute intermittent porphyria by the induction of hepatic 5-aminolaevulinate synthase $(16,17)$.

We conclude that the measurement of porphobilinogen deaminase activity in the erythrocytes is not sufficient for detecting gene carriers in families of acute intermittent porphyria with this variant of normal enzyme activity. In such cases porphobilinogen deaminase mutation analysis must be used. However, for this purpose the specific mutation in the porphobilinogen deaminase gene has to be identified (2). We are able to detect six gene carriers in three acute intermittent porphyria families with normal prophobilinogen deaminase activity by using sensitive metabolite studies.

\section{Acknowledgements}

We thank Sabine Preis, Martina Wenz and Heidrun Schudarek for skilful technical assistance. The study was supported by the HansFischer-Gesellschaft, Munich.

porphyria in a Finnish family with normal erythrocyte porphobilinogen deaminase. Eur J Clin Invest 1989; 19:415-8.

11. Bourgeois F, Gu XF, Deybach JC, Te Velde MP, de Rooij F, Nordmann Y, Grandchamp B. Denaturing gradient gel electrophoresis for rapid detection of latent carriers of a subtype of acute intermittent porphyria with normal erythrocyte porphobilinogen deaminase activity. Clin Chem 1992; 38:93-5.

12. Mazzetti MB, Tomio JM. Human porphobilinogen deaminase, isolation and purification of the hepatic isoform. An Asoc Quim Argent 1993; 81:381-9.

13. Desnick RJ. Ostasiewicz L, Tischler P, Mustajoki P. Acute intermittent porphyria: characterization of a novel mutation in the structural gene for porphobilinogen deaminase. Demonstration of non-catalytic enzyme intermediates stabilized by bound protein. J Clin Invest 1985; 76:865-74.

14. Mustajoki P, Desnick RJ. Genetic heterogeneity in acute intermittent porphyria: characterization and frequency of porphobilinogen deaminase mutations in Finland. $\mathrm{Br}$ Med $\mathrm{J}$ 1985; 291:505-9.

15. Blum M, Koehl C, Abecassis J. Variations in erythrocyte uroporphyrinogen I synthetase activity in non porphyrias. Clin Chim Acta 1978; 87:119-25.

16. Doss M, Schäfer HJ. Carbamazepin-induced acute porphyria syndrome. Lancet 1984; I:1026.

17. Kappas A, Sassa S, Galbraith RA, Nordmann Y. The porphyrias. In: Scriver CR, Beaudet AL, Sly WS, Valle D, editors. The metabolic and molecular bases of inherited disease. New York: McGraw-Hill, 1995:2103-59.

\section{Received February I2/May 5, 1996}

Corresponding author: Prof. Dr. med. Manfred O. Doss, Abteilung für Klinische Biochemie, Fachbereich Humanmedizin und Klinikum der Philipps-Universität, Deutschhausstraße 171/2, D-35037 Marburg, Germany 